\title{
EFFICACY OF TYPE 1 BOVINE COLLAGEN PARTICLES IN THE TOPICAL MANAGEMENT OF DIABETIC FOOT ULCER
}

Ashok. Y. Kshirsagar1, Yash Pandey², Sourav Baur³, Hrishikesh Deka4, Amit Verma 5 , Abhinav Kesarwani', Abhishek Bhagat7, Aniket Surushe 8

1 Professor, Department of General Surgery, Krishna Institute of Medical Sciences Deemed University, Karad.

${ }^{2} 3^{\text {rd }}$ Year Junior Resident, Department of General Surgery, Krishna Institute of Medical Sciences Deemed University, Karad.

33 rd Year Junior Resident, Department of General Surgery, Krishna Institute of Medical Sciences Deemed University, Karad.

${ }_{4}^{4}{ }^{\text {rd }}$ Year Junior Resident, Department of General Surgery, Krishna Institute of Medical Sciences Deemed University, Karad.

${ }^{5} 2^{\text {nd }}$ Year Junior Resident, Department of General Surgery, Krishna Institute of Medical Sciences Deemed University, Karad.

${ }^{62^{\text {nd }}}$ Year Junior Resident, Department of General Surgery, Krishna Institute of Medical Sciences Deemed University, Karad.

$7^{\text {nd }}$ Year Junior Resident, Department of General Surgery, Krishna Institute of Medical Sciences Deemed University, Karad.

$82^{\text {nd }}$ Year Junior Resident, Department of General Surgery, Krishna Institute of Medical Sciences Deemed University, Karad.

\begin{abstract}
Diabetic foot ulcer will lead to a significant prolonged stress to the patients. Biological dressings like type 1 bovine collagen particles has advantage over conventional dressing in terms of early healing of wound. A total of 100 patients suffering from ulcer were taken randomly for this study after explaining the procedure and purpose of study. This was a comparative study between conventional dressing of ulcer and dressing with type 1 bovine collagen particles. There was significant difference in the re sult of collagen granules and conventional dressing. Collagen granules had better healing response rate.
\end{abstract}

\section{AIMS AND OBJECTIVES.}

To study the efficacy of topical agent type 1 bovine collagen granules in the management of diabetic foot ulcers.

\section{METHODOLOGY}

The patients who were admitted for diabetic foot ulcer at Dept. of Surgery, KIMS, Karad, tertiary care teaching centre during the study period were screened. 50 patients in the test group were treated with topical dressings of collagen granules. The control group of 50 patients was treated with conventional topical dressings and bedside debridement. Ulcer was noted using visual score.

\section{RESULTS}

The reduction of slough is as early as $3^{\text {rd }}$ week in test group than the control group. The number of patients with $75-100 \%$ wound filled with granulation tissue is as early as $3^{\text {rd }}$ week in test group than the control group where it took more than 4 weeks. The number of patients who underwent secondary suturing, skin grafting, and flap are significantly higher and also as early as $3^{\text {rd }}$ week in test group than the control group.

\section{CONCLUSION}

Collagen granules topical application enhanced wound healing of diabetic foot ulcer as compared to conventional treatment modalities.

\section{KEYWORDS}

Collagen Particles, Granulation Tissue, Wound.

HOW TO CITE THIS ARTICLE: Kshirsagar AY, Pandey Y, Baur S, et al. Efficacy of type 1 bovine collagen particles in the topical management of diabetic foot ulcer. J. Evolution Med. Dent. Sci. 2016;5(67):4769-4773, DOI: 10.14260/jemds/2016/1087

\section{INTRODUCTION}

During the last decade, various new dressing materials developed like calcium alginate, hydrocolloid membranes, and fine mesh gauze. These have a disadvantage in that they become permeable to bacteria.[1]

Biological dressings like collagen on the other hand create the most physiological interface between the wound surface and environment and are impermeable to bacteria. Collagen dressings have other advantages over conventional dressings in terms of ease of application and being natural,

Financial or Other, Competing Interest: None.

Submission 26-05-2016, Peer Review 06-07-2016,

Acceptance 13-07-2016, Published 20-08-2016.

Corresponding Author:

Dr. Yash Pandey,

Department of General Surgery,

Krishna Institute of Medical Sciences Deemed University,

Karad.

E-mail: dryash21@gmail.com

DOI: $10.14260 /$ jemds/2016/1087 non-immunogenic, non-pyrogenic, hypoallergenic, and painfree. The present study has been conducted to compare the efficacy of collagen dressing with that of conventional dressing materials like silver sulfadiazine, nadifloxacin, povidone iodine, or honey (used traditionally) in the management of diabetic ulcer wounds.

Collagen is defined as an endogenous substance, which forms an important structural component in connective tissue and is of special importance in the skin. The importance of collagen in healing has been appreciated for many years for the simple reason that the result of repair in wound healing is always a scar, which is composed of collagenous fibers. ${ }^{[2]}$ Collagen forms molecular diversity in the body's protein scaffold. [3]

Collagen granule dressing has better advantage over conventional dressing in terms of collagen formation with greater reduction in inflammatory cells during healing days resulting in decreased days of healing, whereas conventional 
dressing has minimal collagen formation, high grade of inflammation during the healing days with maximum exudates formation resulting in increased days of healing. A collagen granule dressing has another advantage over conventional dressing in terms of nonimmunogenic, nonpyrogenic, being natural, easy application, hypoallergic, and pain free.[4]

\section{MATERIAL AND METHODS}

The present prospective comparative trial was conducted in the patients who were admitted with diabetic foot ulcer in of a tertiary care teaching centre. Patients admitted for diabetic foot ulcer between January 2015 to February 2016 screened for a period of 12 weeks and those who fulfilled the inclusion criteria were included in study. Finally, sample size was 100 out of which 50 were in test group and 50 were in control group.

\section{Inclusion Criteria}

Patients aged more than 20 yrs. with diabetic foot ulcer.

\section{Exclusion Criteria}

Malnutrition.

\section{Haemoglobin $<12$ gm\%}

Other clinically significant medical conditions that would impair wound healing including renal, hepatic, haematological, neurological, cardiovascular, and immunological diseases.

Patients receiving corticosteroids, immunosuppressive agents, radiation, or chemotherapy within one month prior to entry into the study were also excluded.

\section{OBSERVATION AND RESULT}

\section{Age Distribution}

Most of the patients fell in the age group between 40 yrs. to 70 yrs. The mean \pm SD for test group is $(55.1 \pm 12.1)$ and control is $(54.9 \pm 13.19)$, so age distribution is statistically similar between two group with $\mathrm{P}>0.05$.

\begin{tabular}{|c|c|c|c|c|}
\hline \multirow{2}{*}{$\begin{array}{c}\text { Age in } \\
\text { Years }\end{array}$} & \multicolumn{2}{|c|}{ Study Group } & \multicolumn{2}{c|}{ Control Group } \\
\cline { 2 - 5 } & \multicolumn{2}{|c|}{ No. of Cases \% } & \multicolumn{2}{c|}{ No. of Cases \% } \\
\hline $21-30$ & 01 & 02 & 02 & 04 \\
\hline $31-40$ & 04 & 08 & 04 & 08 \\
\hline $41-50$ & 17 & 34 & 17 & 34 \\
\hline $51-60$ & 12 & 24 & 11 & 22 \\
\hline $61-70$ & 14 & 28 & 13 & 26 \\
\hline $71-80$ & 01 & 02 & 01 & 02 \\
\hline$>80$ & 01 & 02 & 02 & 04 \\
\hline Total & $\mathbf{5 0}$ & $\mathbf{1 0 0 . 0}$ & $\mathbf{5 0}$ & $\mathbf{1 0 0 . 0}$ \\
\hline Mean \pm SD & \multicolumn{3}{|c|}{$55.1 \pm 12-1$} & \multicolumn{3}{l|}{ Age distribution is statistically similar } \\
\hline \multirow{2}{*}{ Inference } & \multicolumn{3}{|c|}{ between the two groups P >0.05 insignificant } \\
\hline
\end{tabular}

\section{Diabetes Mellitus Status}

Most of the patients in test (62\%) and control (60\%) group had previous history of diabetes mellitus. The newly-detected groups are $38 \%$ and $40 \%$ in test and control groups respectively.

\begin{tabular}{|c|c|c|c|c|}
\hline \multirow{2}{*}{$\begin{array}{c}\text { Diabetes } \\
\text { Mellitus }\end{array}$} & \multicolumn{2}{|c|}{$\begin{array}{c}\text { Test Group } \\
(\mathbf{n = 5 0 )}\end{array}$} & \multicolumn{2}{c|}{$\begin{array}{c}\text { Control Group } \\
(\mathbf{n = 5 0 )}\end{array}$} \\
\cline { 2 - 5 } & No. & $\%$ & No. & $\%$ \\
\hline Present & 31 & 62 & 30 & 60 \\
\hline $\begin{array}{c}\text { Newly } \\
\text { detected }\end{array}$ & 19 & 38 & 20 & 40 \\
\hline Total & $\mathbf{5 0}$ & $\mathbf{1 0 0}$ & $\mathbf{5 0}$ & $\mathbf{1 0 0}$ \\
\hline \multirow{2}{*}{ Inference } & \multicolumn{2}{|c|}{$\begin{array}{c}\text { Diabetes mellitus is equally distributed } \\
\text { between the two group with respect to } \\
\text { present and newly-detected cases }\end{array}$} \\
\hline
\end{tabular}

\section{Duration of Diabetes Mellitus}

It is observed in our study, most of the patients presented with diabetes mellitus of duration with Mean \pm SD of test group $5.68 \pm 6.28$ and control group $5.4 \pm 6.1$ thus showing long duration of diabetes mellitus. Patients are prone for diabetic foot ulcers.

\begin{tabular}{|c|c|c|c|c|}
\hline $\begin{array}{c}\text { Duration of } \\
\text { Diabetes } \\
\text { Mellitus }\end{array}$ & \multicolumn{2}{|c|}{ Nest Group (n=50) Control group (n=50) } \\
\cline { 2 - 5 }$\leq 5$ years & 26 & 52 & 25 & 50 \\
\hline 5-10 years & 13 & 13 & 12 & 24 \\
\hline 11-20 years & 10 & 10 & 13 & 26 \\
\hline$>20$ years & 01 & 01 & 00 & 00 \\
\hline Mean \pm SD & \multicolumn{2}{|c|}{$5.68 \pm 6.28$} & & \\
\hline \multicolumn{4}{|c|}{$\begin{array}{c}\text { Diabetes mellitus is equally distributed } \\
\text { between the two groups with respect to } \\
\text { duration }\end{array}$} \\
\hline
\end{tabular}

$\mathrm{P}>0.05$ Insignificant

\section{Size of Ulcers}

The mean size of ulcer was 11.26 to $11.3 \mathrm{~cm}$. The mean \pm SD of the size of ulcer in test group $(11.26 \pm 4.32)$ and in control group $(11.3 \pm 4.32)$ is statistically similar between the two groups with $\mathrm{p}>0.05$.

\section{Size of the Ulcers}

\begin{tabular}{|c|c|c|c|c|}
\hline $\begin{array}{c}\text { Size of Ulcer } \\
\text { (cm) }\end{array}$ & $\begin{array}{c}\text { Test Groups (n=50) } \\
\text { No. \% }\end{array}$ & \multicolumn{2}{c|}{$\begin{array}{c}\text { Control Group } \\
\text { (n=50) No. \% }\end{array}$} \\
\hline$\leq 5$ & 02 & 04 & 03 & 06 \\
\hline $5-10$ & 26 & 52 & 25 & 50 \\
\hline $11-20$ & 21 & 42 & 20 & 40 \\
\hline$>20$ & 01 & 02 & 02 & 04 \\
\hline Mean \pm SD & \multicolumn{2}{|c|}{$11.26 \pm 4.32$} & \multicolumn{2}{c|}{$11.3 \pm 4.32$} \\
\hline Inference & \multicolumn{4}{|c|}{ Size of ulcer is statistically similar between } \\
\end{tabular}

$\mathrm{p}>0.05$ insignificant

\section{Presence of Granulation Tissue}

The number of patients with $75-100 \%$ wound filled with granulation tissue are significantly higher in test group at $3^{\text {rd }}$ week followup $(\mathrm{p}<0.001)$, at $4^{\text {th }}$ week $(\mathrm{p}<0.001)$, at $5^{\text {th }}$ week $(\mathrm{p}<0.001)$, at $6^{\text {th }}$ week $(\mathrm{p}<0.001)$, and at $7^{\text {th }}$ week $(\mathrm{p}<0.05)$.

\begin{tabular}{|c|c|c|c|c|c|c|c|c|}
\hline \multirow{2}{*}{$\begin{array}{l}\text { Study } \\
\text { Period }\end{array}$} & \multicolumn{4}{|c|}{ Test Group $(n=50)$} & \multicolumn{4}{|c|}{$\begin{array}{c}\text { Control Group } \\
(n=50)\end{array}$} \\
\hline & 1 & 2 & 3 & 4 & 1 & 2 & 3 & 4 \\
\hline Baseline & 26 & 21 & 03 & 00 & 25 & 22 & 03 & 00 \\
\hline $1^{\text {st }} \mathrm{wk}$. & 35 & 13 & 01 & 00 & 40 & 08 & 02 & 01 \\
\hline $2^{\text {nd }} w \mathrm{k}$. & 09 & 39 & 01 & 01 & 25 & 20 & 04 & 01 \\
\hline $3^{\text {rd }}$ wk. & 01 & 33 & 14 & 02 & 16 & 23 & 10 & 03 \\
\hline $4^{\text {th }} \mathrm{wk}$. & 00 & 07 & 38 & 05 & 06 & 18 & 23 & 17 \\
\hline $5^{\text {th }} \mathrm{wk}$. & 00 & 03 & 15 & 32 & 01 & 14 & 18 & 30 \\
\hline $6^{\text {th }} \mathrm{wk}$. & 00 & 01 & 06 & 43 & 00 & 06 & 14 & 40 \\
\hline $7^{\text {th }}$ wk. & 00 & & & 50 & & & 10 & \\
\hline Inference & \multicolumn{8}{|c|}{$\begin{array}{l}\text { Number of patients with } 75-100 \% \text { wound } \\
\text { filled are significant higher in test group at } 3^{\text {rd }} \\
\text { followup }(\mathrm{p}<0.001) \text {, at } 4^{\text {th }} \text { week }(\mathrm{p}<0.001) \text {, at } \\
5^{\text {th }} \text { week }(\mathrm{p}<0.001) \text {, at } 6^{\text {th }} \text { week }(\mathrm{p}<0.001) \text {, } \\
\text { and at } 7^{\text {th }} \text { week }(\mathrm{p}<0.05) .\end{array}$} \\
\hline
\end{tabular}

Commonest Organism are: Aerobic/Anaerobes

\section{Aerobes}

1. Gram-positive bacilli

Enterococcus SP 
S. aureus

Group B Streptococcus.

2. Gram-negative bacilli

P. mirabilis

E. coli

P. aeruginosa.

\section{Anaerobes}

1. Gram-negative bacilli B. fragilis

2. Gram-positive bacilli P. anaerobes

Thus, the infections are polymicrobial in DM.

\section{Antibiotic Therapy}

Virtually, all diabetic foot infections require antimicrobial therapy; but it is important to remember that while this is a necessary step, it is rarely sufficient. [5]

Antimicrobial treatment of foot infections in patients with diabetes is begun empirically and thereafter revised based on the results of cultures, which were obtained prior to therapy and on occasion during therapy and the clinical response of the infection.

\begin{tabular}{|c|c|}
\hline Infections & Antimicrobial Regimen \\
\hline \multirow{2}{*}{$\begin{array}{c}\text { Non-limb } \\
\text { threatening }\end{array}$} & Cephalexin 500 mg p.o. q. 8h. \\
\cline { 2 - 2 } & Amoxicillin - potassium clavulanate 1.2 \\
& g q. 12h. \\
\hline \multirow{2}{*}{$\begin{array}{c}\text { Limb } \\
\text { threatening }\end{array}$} & \begin{tabular}{c} 
ampicillin/sulbactam 3 g IV q. 8h. \\
\cline { 2 - 2 }
\end{tabular} \\
\cline { 2 - 2 } & Fluoroquinolones IV plus \\
& metronidazole 500 mg IV q. 8h. \\
\hline
\end{tabular}

\section{Wound Surface Area}

The number of patients with no wound surface (Nil) are significantly higher in test group at $3^{\text {rd }}$ week followup $(\mathrm{p}<0.05)$, at $4^{\text {th }}$ week $(\mathrm{p}<0.05)$, at $5^{\text {th }}$ week $(\mathrm{p}<0.05)$, at $6^{\text {th }}$ week $(p<0.001)$, and at the 7 th week $(p<0.001)$ when compared to control group as per chi-square/Fisher exact test.

\begin{tabular}{|c|c|c|c|c|c|c|c|c|}
\hline \multirow{3}{*}{$\begin{array}{l}\text { Study } \\
\text { Period }\end{array}$} & \multicolumn{4}{|c|}{ Test Group (n=50) } & \multicolumn{4}{|c|}{ Control Group $(n=50)$} \\
\hline & \multicolumn{8}{|c|}{ Wound Surface Area (cm2) } \\
\hline & $>10$ & $5-10$ & $1-5$ & Nil & $>10$ & $5-10$ & $1-5$ & Nil \\
\hline Baseline & 22 & 26 & 02 & 00 & 23 & 25 & 02 & 00 \\
\hline $1^{\text {st }}$ week & 22 & 26 & 02 & 00 & 28 & 19 & 03 & 00 \\
\hline $2^{\text {nd }}$ week & 16 & 30 & 04 & 00 & 26 & 21 & 03 & 00 \\
\hline $3^{\text {rd }}$ week & 14 & 29 & 07 & 00 & 20 & 26 & 04 & 00 \\
\hline $4^{\text {th }}$ week & 07 & 25 & 16 & 02 & 16 & 28 & 06 & 00 \\
\hline $5^{\text {th }}$ week & 04 & 16 & 20 & 10 & 12 & 23 & 09 & 06 \\
\hline $6^{\text {th }}$ week & 04 & 02 & 26 & 18 & 12 & 18 & 08 & 12 \\
\hline $7^{\text {th }}$ week & 01 & 00 & 07 & 42 & 10 & 14 & 06 & 20 \\
\hline Inference & \multicolumn{8}{|c|}{$\begin{array}{l}\text { Number of patients with no wound surface (Nil) are significantly higher in Test group at } 3^{\text {rd }} \text { week followup } \\
(p<0.05) \text {, at } 4^{\text {th }} \text { week }(p<0.05) \text {, at } 5^{\text {th }} \text { week }(p<0.05) \text {, at } 6^{\text {th }} \text { week }(p<0.001) \text {, and at the } 7^{\text {th }} \text { week }(p<0.001) \text { when } \\
\text { compared to control group as per the chi-square } / \text { Fisher Exact test. }\end{array}$} \\
\hline
\end{tabular}

Nil-flap, Healed, SSG, and Secondary Suturing.

\section{DISCUSSION}

The number of patient studied was 100 and randomly divided into test group (50) and control group (50). Both the test and control groups were matched regarding their age, diabetic status, and nutritional status. The number of patients with no necrotic tissue is significantly higher in test group at $3^{\text {rd }}$ week followup $(\mathrm{p}<0.001)$, at $4^{\text {th }}$ week $(\mathrm{p}<0.001)$, at $5^{\text {th }}$ week $(\mathrm{p}<0.001)$, at $6^{\text {th }}$ week $(\mathrm{p}<0.001)$, and at the $7^{\text {th }}$ week $(\mathrm{p}<0.01)$ when compared to control group. There is minimal loss of viable tissue in the test group compared to control group because the number of bedside surgical debridement required is less and done superficially to remove dead tissue only.

The number of patients with $75-100 \%$ wound filled by granulation tissue is significantly higher in test group at $3^{\text {rd }}$ week followup ( $p<0.001)$, at $4^{\text {th }}$ week $(p<0.001)$, at $5^{\text {th }}$ week $(\mathrm{p}<0.001)$, at $6^{\text {th }}$ week $(\mathrm{p}<0.001)$, and at 7 th week $(\mathrm{p}<0.005)$ when compared to control group.

The number of patients with no wound surface (nil) is significantly higher in test group at 3 rd week followup $(\mathrm{p}<0.05)$, at $4^{\text {th }}$ week $(\mathrm{p}<0.05)$, at $5^{\text {th }}$ week $(\mathrm{p}<0.05)$, at $6^{\text {th }}$ week $(p<0.001)$, and at the $7^{\text {th }}$ week $(p<0.001)$ when compared to control group.

The duration of hospital stay was less in test group compared to control group.
Various factors have been implicated for an ulcer to develop in diabetic patients of which important is peripheral vascular disease, which causes decrease in sensation as a result of peripheral neuropathy.[6] Secondary infection in a chronic ulcer is very common that will have a copious amount of discharge that smells foul. Antibiotic treatment for infection, wound dressing, pressure relief (special footwear, offloading, inserts, and casting), debridement, and desloughing are the traditional management approaches for diabetic ulcers. ${ }^{[7]}$ Embarrassing dressings, restricted mobility, and disability are the other issues that are often a great concern to the patients. ${ }^{[8]}$

Collagens functions as structural proteins of extracellular matrix and are synthesised by the fibroblasts.[9,10] In normal wound healing process, special enzymes called matrix metalloproteinases (MMPs) breaks down the malformed and damaged collagen present at the site of wound. So, when dressings containing collagen are used, the MMPS are kept busy breaking down that collagen and the healthy collagen that is innate of the body is thus protected helping in hastening the healing process.[11] There are other modalities of dressing other than conventional Betadine dressing in ulcer management like sugar dressing, vacuum-assisted closure method. Direct instillation of sugar on the wound will result in low osmolar effect, promoting early granulation tissue 
formation, reduction in oedema. Hence, bacteriostatic effect is enhanced and thereby hastens the wound healing.[12,13] Knutson and colleagues performed a study on wounds treated with granular sugar with povidone iodine to treat 605 patients with traumatic wounds and burns and observed reduction in healing time by $25 \% .{ }^{[14]}$ But, there is still a lack in evidence explaining the cellular and molecular interactions between sugar and wound environment where in our study a molecular basis is explained. Vacuum-assisted wound closure is a recent and significant method of wound closure management. This method was first described by Fleishmann in 1993.[15] This method works on application of controlled negative pressure on wound bed.

Gradual traction on living tissues can stimulate and promote regeneration of tissue structures. Morykwas et al studies showed decrease in the bacterial load in wounds treated with negative pressure therapy.[16] There should be complete haemostasis before application of vacuum dressing and this has to be used in caution in patients with coagulopathies.

Collagen serves as the key extracellular component for repair and remodeling of skin tissue. As a biomaterial, collagen offers several advantages over traditional dressings, growth hormones, and biological coverings.[17] The use of collagen as a drug delivery system is very comprehensive and diverse. Collagen can be extracted into an aqueous solution and molded into various forms of delivery systems. Due to its excellent biocompatibility and safety, the use of collagen in biomedical application has been rapidly growing and widely expanding to bioengineering areas.[18] Collagen appears to be a good material for use as a biomedical implantable device and is used to form a matrix for regenerating tissue outside of the body, for example in regenerating skin for use in burns treatment, but increasingly it is also used in the development of other tissues offering the prospect of growing replacements for damaged organs. Collagen membranes are also chemotactic for regenerative cells and may enhance the migration and attachment of fibroblasts through its space-making ability.[19]

Present study is a prospective study regarding collagen dressing versus conventional dressing. It was conducted between January 2015 to February 2016 in which 100 patients who presented with diabetic foot ulcer.

Various aetiologies were chosen by random sampling technique and were grouped into two groups consisting of 50 patients each to show the efficacy of collagen dressing.

The patient treated with collagen granules has faster reduction of slough/necrotic tissue and increased granulation tissue compared to study by OMKAR SINGH AND HARISH RAO.

Omkar Singh study reveals that regarding Collagen Dressing Versus Conventional Dressings in 120 patients with chronic wounds of varied aetiologies and with mean age 43.7 yrs. with two weeks of treatment, $60 \%$ of the 'collagen group' wounds, and only $42 \%$ of the 'conventional group' wounds were sterile $(\mathrm{P}=0.03)$.

Healthy granulation tissue appeared earlier over collagendressed wounds than over conventionally treated wounds $(\mathrm{P}=0.03)$. After eight weeks, 52 (87\%) of 'collagen group' wounds and $48(80 \%)$ of 'conventional group' wounds were $>75 \%$ healed $(\mathrm{P}=0.21)$. Eight patients in the 'collagen group' and 12 in the 'conventional group' needed partial split-skin grafting $(\mathrm{P}=0.04)$. Collagen-treated patients enjoyed early and more subjective mobility. No significant better results in terms of completeness of healing of burn and chronic wounds between collagen dressing and conventional dressing were found. Collagen dressing, however, may avoid the need of skin grafting and provides additional advantage of patients' compliance and comfort.

In another study by Harish Rao regarding collagen dressings versus conventional dressings in wound healing of 100 patients with diabetic foot ulcer. In 75 patients collagen dressing was applied whereas conventional dressing in 25 patients. On enrollment, the median wound size was $33.5 \mathrm{~cm} 2$ in collagen dressing group and $48 \mathrm{~cm} 2$ in conventional dressing group. Healing time $(4.02 \pm 0.59$ vs. $7.6 \pm 1.38)$, duration of antibiotic therapy (15.12 \pm 4.55 vs $24.08 \pm 6.5)$, and mean followup period $(2.40 \pm 0.61$ vs. $2.96 \pm 1.2)$ were significantly less in collagen dressing group as compared to conventional dressing group $(\mathrm{P}<0.001)$. No adverse event was reported in both the groups. Collagen dressing is safe and effective in the treatment of foot ulcer and significantly reduces healing time, duration of antibiotic therapy, and followup time.

The present study made a comparison between the collagen dressing and conventional dressing. The efficacy and wound healing capacity of both the methods were gauged using suitable statistical test. The study revealed some interesting results: The study demonstrated that collagen granules dressing along with bedside surgical debridement had cumulative effect in reduction of slough, increase granulation tissue, and faster wound bed preparation.

The test group patients had increased growth of granulation tissue along with epithelisation, which is generally correlated with the development of a granulating wound bed. All this are done with visual score, so it cannot be determined whether there was increase in granulation tissue production resulting from the treatment or that more granulation was visible after debridement. But, patients in test group produced better result than control group.

The test group underwent skin grafting, secondary suturing, and flap as early as $3^{\text {rd }}$ week than control group because of faster wound bed preparation. The wound also healed faster because of increased epithelisation.

\section{CONCLUSION}

1. The study was done to give an insight to the depth of diabetic wound management as it has become a foremost problem in recent era.

2. The goal of this study was to enhance the wound/ulcers to be avoid of necrotic tissue and debris and to remove the senescent cells from the wound bed using type I Bovine Collagen Granules as the agents and preparing the wound for a healthy bed of granulation tissue to promote a rapid healing.

3. This is achieved in our study by using type 1 Bovine Collagen Granules, which is proved to be highly effective in reduction of slough, promoting granulation tissue formation, and reepithelialisation.

4. Type 1 Bovine Collagen Granule prove to be significantly effective in wound bed preparation in comparison with conventional treatment with local antiseptics. 


\section{REFERENCES}

1. Park SN, Lee HJ, Lee KH, et al. Biological characterisation of EDC-crosslinked collagen-hyaluronic acid matrix in dermal tissue restoration. Biomaterials 2003;24(9):1631-41.

2. Sai PK, Babu M. Collagen based dressings-a review. Burns 2000;26(1):54-62.

3. Murry RK, Keeley FW. Harper's illustrated biochemistry: the extracellular matrix. 27th edn. 2006:545-8

4. Singh 0, Gupta SS, Mathur RK, et al. Collagen dressing versus conventional dressings in burn and chronic wounds: a retrospective study. J Cutan Aesthet Surg 2011;4(1):12-6.

5. Pal US, Singh RK, Mohammad S, et al. Use of collagen in extraoral wounds. J Maxillofac Oral Surg 2009;8(3):261264.

6. Lee $\mathrm{CH}$, Singla A, Lee Y. Biomedical applications of collagen. International Journal of Pharmaceutics 2001;221(1-2):1-22.

7. Enoch S, Leaper DJ. Basic Science of wound healing. Elsevier Surgery 2005;23(2):37-42.

8. Pudner R. Wound management. The management of patients with a leg ulcer. Journal of Community Nursing 1998;12(3):26-33.

9. Blume PA, Walters J, Payne W, et al. Comparison of negative pressure wound therapy using vacuum-assisted closure with advanced moist therapy in the treatment of diabetic foot ulcers. A multicenter randomised controlled trial. Diabetes Care 2008;31(4):631-6.

10. Bauling PC. A review of the impact of dressings on quality of life. In: Suggett A, Cherry G, Mani R, et al eds. Evidencebased wound care: proceedings of a conference sponsored by Smith and Nephew held in New York, UK on 17th November 1997. London: Royal society of Medicine Press 1998:39-42.
11. Heino J. The collagen family members as cell adhesion proteins. BioEssays 2007;29(10):1001-10.

12. Myllyharju J, Kivirikko KI. Collagens, modifying enzymes, and their mutations in humans, flies, and worms. Trends in Genetics 2004;20(1):33-43.

13. Barbul A, Etron DT. Wound healing. In: Brunicardi CF, ed. Schwart'z Principles of Surgery. 9th edn. New York: McGraw Hill 2010:209-31.

14. Chirife J, Herszage L, Joseph A, et al. In vitro study of bacterial growth inhibition in concentrated sugar solutions: microbiological basis for the use of sugar in treating infected wounds. Antimicrob Agents Chemother 1983;23(5):766-73.

http://www.ncbi.nlm.nih.gov/pmc/articles/PMC45255 46/ 6/6.

15. Chirife J, Scarmato G, Herszage L. Scientific basis for use of granulated sugar in treatment of infected wounds. Lancet 1982;1(8271):560-1.

16. Knutson RA, Merbitz LA, Creekmore MA, et al. Use of sugar and povidone-iodine to enhance wound healing: five years' experience. South Med J 1981;74(11):132935.

17. Cohen IK, Diegelmann RF, Yager DR, et al. Wound care and wound healing. In: Shires G, Spencer F, et al eds. Schwartz's Principles of Surgery. 7th edn. New York: McGrawHill 1999:263-95.

18. Morykwas MJ, Simpson J, Punger K, et al. Vacuumassisted closure: state of basic research and physiologic foundation. Plast Reconstr Surg 2006;117(suppl 7):121S-126S.

19. Lipsky BA. Evidence-based antibiotic therapy of diabetic foot infections. FMES immunol Med Microbial 1999;26(3-4):267-76. 